\title{
Methylprednisolone pulse therapy for nonrenal lupus erythematosus
}

\author{
STEVEN EYANSON, MURRAY H. PASSO, MARLENE A. ALDO-BENSON, \\ AND MERRIL D. BENSON
}

From the Rheumatology Section, Department of Medicine, Indiana University School of Medicine, Indianapolis, USA

SUMMARY High-dose intravenous methylprednisolone therapy has previously been shown to be efficacious in the treatment of renal lupus erythematosus. The present report presents 2 patients with life-threatening, nonrenal lupus erythematosus. One patient had coma and seizures, while the other had severe thrombocytopenia and anaemia. Both had failed to respond to oral corticosteroid therapy in high doses but had dramatic clinical responses with intravenous methylprednisolone given in 'pulses.' Possible mechanisms of clinical improvement are discussed.

High-dose intravenous methylprednisolone given in 'pulses' has become an established therapy for the prevention of acute renal graft rejection. ${ }^{12}$ Each pulse consists of an intermittent large dose of intravenous methylprednisolone given over several days. This form of therapy has also been tried in severe glomerulonephritis ${ }^{3}$ and in proliferative lupus nephritis ${ }^{4-6}$ with improvement in clinical and laboratory parameters of renal disease activity.

While previous reports have shown reversal of deteriorating renal function in lupus erythematosus, ${ }^{4-6}$ little is known about the effects of pulse therapy in life-threatening, nonrenal manifestations of systemic lupus erythematosus (SLE). We report 2 cases of patients with life-threatening, nonrenal complications of SLE, one with central nervous system (CNS) involvement and one with haemolysis and thrombocytopenia, in which large doses of intravenous methylprednisolone were given after clinical failure with large doses of oral prednisone.

\section{Patients and materials}

CASE 1

A 23-year-old white female was admitted to hospital in December 1977 with a 4-month history of fever, myalgias, arthralgias, alopecia, and facial rash. The patient had previously been in good health except

Accepted for publication 22 August 1979.

Correspondence to Dr Marlene Aldo-Benson, Rheumatology Division, Indiana University School of Medicine, 1100 West Michigan Street, Indianapolis, Indiana, 46223, USA. for psoriasis of 11 years' auration recently treated with psoralen and ultraviolet light (PUVA).

In August 1977, within 1 day of a heavy sun exposure, she developed fevers, arthralgias, myaligas, and a macular rash on the face, shoulders, and back. Despite treatment with a brief course of $10 \mathrm{mg}$ prednisone daily and aspirin, her rash and other symptoms persisted. In October 1977 serum fluorescent antinuclear antibodies (FANA) were detected at a titre of 1:100 with normal serum C3 and $\mathrm{C} 4$. Proteinuria of $1.3 \mathrm{~g}$ per 24 hours was detected.

On admission in December 1977 physical examination revealed an oral temperature of $38 \cdot 6^{\circ} \mathrm{C}$. There was a blotchy erythematous rash on the face, forehead, back, and shoulders, diffuse alopecia, and typical psoriatic plaques at the elbows and knees. The spleen was palpable at the left costal margin.

Laboratory evaluation included a haemoglobin of $11 \cdot 3 \mathrm{~g} / \mathrm{dl}$ and white blood cell count of $3 \cdot 2 \times 10^{9} / 1$ with $30 \%$ bands, $49 \%$ polymorphonuclear cells, $9 \%$ lymphocytes, $10 \%$ monocytes, and $2 \%$ eosinophils. Urine analysis showed only proteinuria, and a 24-hour urine collection showed $4 \cdot 5 \mathrm{~g}$ of protein and a creatinine of $87 \mathrm{ml} / \mathrm{min}$. Serum fluorescent antinuclear antibodies (FANA) were detected at a titre of 1:512 with homogeneous pattern, and the Westergren sedimentation rate was $88 \mathrm{~mm} / \mathrm{h}$. Serum C3 was $150 \mathrm{mg} / 100 \mathrm{ml}$ (normal 87 to 204) and C4 was $24 \mathrm{mg} / 100 \mathrm{ml}$ (normal 15 to 24). Serum IgG was $1700 \mathrm{mg} / 100 \mathrm{ml}$ (normal 655 to 1551), serum IgA was $300 \mathrm{mg} / 100 \mathrm{ml}$ (normal 63 to 390 ), and 
IgM was $150 \mathrm{mg} / 100 \mathrm{ml}$ (normal 60 to 347). (SI: $\mathrm{mg} / \mathrm{l}=\mathrm{mg} / 100 \mathrm{ml} \times 10$.)

A renal biopsy showed focal mesangial proliferation. A skin biopsy from the right elbow showed hyperkeratosis, parakeratosis, regular acanthosis, and a mild perivascular inflammation consistent with psoriasis. A second biopsy from the back showed follicular plugging, thinning of the epidermis, and chronic perivascular and periappendaged inflammation 'consistent' with lupus. An immunofluorescent band test was done on uninvolved skin and showed only stippling for $\mathrm{C} 3$ at the dermal-epidermal junction.

Initially the patient responded to aspirin, though fever and proteinuria recurred. $40 \mathrm{mg}$ of prednisone daily was added with improvement in clinical condition, though her serum C3 fell to $62 \mathrm{mg} / 100 \mathrm{ml}$ and serum $\mathrm{C} 4$ to $9 \mathrm{mg} / 100 \mathrm{ml}$ and remained low. A repeat serum FANA titre was 1:1024. Antibodies to extractable nuclear antigens were found at 1:100 000, with both RNAase-sensitive RNP and Sm antibodies being present.

In February 1978, after the dose of oral prednisone had been slowly tapered to $25 \mathrm{mg}$ daily, the patient developed high fevers, grand mal seizures, and obtundation. A single cytoid body was observed. The cerebrospinal fluid showed $40 \mathrm{WBC} / \mathrm{mm}^{3}, 60 \%$ of which were lymphocytes and the rest polymorphonuclear cells. The cerebrospinal fluid (CSF) protein was $147 \mathrm{mg} / 100 \mathrm{ml} .(1 \cdot 47 \mathrm{~g} / \mathrm{l})$ Despite $100 \mathrm{mg}$ of daily oral prednisone the patient deteriorated rapidly with coma and seizures. Adequate levels of phenytoin and phenobarbitol were ineffective in controlling seizures.

$1 \mathrm{~g}$ of intravenous methylprednisolone was given daily as a single dose for 3 days with complete resolution of neurological symptoms and fever. Within 1 week of methylprednisolone therapy serum C3 was $155 \mathrm{mg} / 100 \mathrm{ml}$ and $\mathrm{C} 432 \cdot 8 \mathrm{mg} / 100 \mathrm{ml}$ and have remained normal. The Westergren sedimentation rate rapidly decreased to $18 \mathrm{~mm} / \mathrm{h}$ and proteinuria disappeared. Serum IgG decreased to 960 $\mathrm{mg} / 100 \mathrm{ml}$, serum IgA to less than $60 \mathrm{mg} / 100 \mathrm{ml}$, and $\mathrm{IgM}$ to $62 \mathrm{mg} / 100 \mathrm{ml}$. Repeat lumbar puncture revealed normal CSF findings.

Ten months later the patient is clinically well except for alopecia on $50 \mathrm{mg}$ of prednisone daily.

\section{CASE 2}

A 49-year-old black female was admitted to the hospital in March 1978 with complaints of weakness, dizziness, and shortness of breath of 4 months' duration. The patient had noticed weight loss despite a good appetite. She complained of stiffness and arthralgias, primarily in her hands, of 6 months, duration.
Her past history was remarkable in that the bone marrow was examined for anaemia after an operation for ovarian cyst in 1969 and showed a plasmacytosis. No cause was established. Hyperthyroidism was diagnosed in 1972 , treated initially with ${ }^{131}$ I and subsequently with propylthiouracil and propranolol. These were discontinued in May 1977 for a leucopenia which quickly resolved.

Physical examination on admission revealed frontotemporal alopecia, a dense right cataract, and a left iridectomy scar. Lymph nodes were palpable in the cervical, periauricular, axillary, and epitroclear regions. A grade II/VI systolic ejection murmur was audible at the base and left sternal border. Liver span was $12 \mathrm{~cm}$, with $3 \mathrm{~cm}$ palpable below the costal margin. The spleen was not enlarged. The joints were normal except for chronic, post-traumatic changes of the right knee. Neurological testing gave normal results.

Laboratory tests on admission showed a normal chest $x$-ray and electrocardiogram. Haemaglobin was $7 \cdot 1 \mathrm{~g} / \mathrm{dl}$, leucocytes $7.6 \times 10^{9} / \mathrm{l}$, reticulocyte count $1.6 \%$, and platelets $120 \times 10^{9} / 1$. (A blood count done 2 weeks before admission in evaluation of a self-limited episode of diarrhoea showed a haemoglobin $9.9 \mathrm{~g} / \mathrm{dl}$ ). Urine analysis, liver function tests, and serum electrolytes were normal. The Westergren sedimentation rate was $114 \mathrm{~mm} / \mathrm{h}$.

The hospital course was marked by intermittent febrile episodes, though multiple blood, urine, and sputum cultures were negative. She received 2 units of packed red blood cells on admission. Subsequently she developed a positive direct Coombs test, and her haemoglobin again fell to $7.0 \mathrm{~g} / \mathrm{dl}$. Serum haptoglobin decreased from $200 \mathrm{mg} / 100 \mathrm{ml}$ (normal 35 to 200 ) to $0 \mathrm{mg} / 100 \mathrm{ml}$, and urine haemosiderin was found. The platelet count plunged to $13 \times 10^{9} / 1$. The clotting profile revealed normal prothrombin time and partial thromboplastin time, low normal fibrinogen levels of $167 \mathrm{mg} / 100 \mathrm{ml}$ (normal 150 to 450 ) and positive fibrin split products of greater than $40 \mu \mathrm{g} / \mathrm{ml}$ (normal $<20 \mu \mathrm{g} / \mathrm{ml}$ ). Bone marrow aspirations on 2 occasions revealed plasmacytosis, increased iron stores, and megakaryocytes. Haematology consultants considered the clotting aberrations were secondary to chronic disseminated intravascular coagulation.

Further examination showed normal upper gastrointestinal $x$-ray and barium enema. intravenous pyelogram, gallium scan, bone scan, and abdominal ultrasound. A liver-spleen scan revealed hepatomegaly with uniform uptake. A thyroid scan showed slight enlargement and increased uptake of $42 \%$ (normal up to $35 \%$ ), though thyroid function tests were normal. Lymph node biopsy showed a foilicular, nodular pattern with no evidence of neoplasia or 
vasculitis. Serum FANA was positive on 2 determinations at 1:5120, with homogeneous pattern. Serum rheumatoid factor by latex agglutination was positive at $1: 160$, and quantitative tests for immunoglobins revealed IgG $1720 \mathrm{mg} / 100 \mathrm{ml}$ (normal 800 to to 1800 ), IgA $860 \mathrm{mg} / 100 \mathrm{ml}$ (normal 70 to 360 ), and IgM $170 \mathrm{mg} / 100 \mathrm{ml}$ (normal 70 to 250 ). Total haemolytic complement (CH50) was markedly reduced at $17 \%$ (normal 35 to $65 \%$ ) and serum $\mathrm{C} 3$ was reduced to $35 \mathrm{mg} / 100 \mathrm{ml}$ (normal 88 to 250 ). Serum C4 was normal at $16 \mathrm{mg} / 100 \mathrm{ml}$ (normal 12 to 75). Renal function tests showed creatinine clearance $77 \mathrm{ml} / \mathrm{min}$ and 24-hour total protein of $150 \mathrm{mg}$. Urine analysis remained normal except during one episode of urinary tract bleeding. (SI: $\mathrm{mg} / \mathrm{l}=$ $\mathrm{mg} / 100 \mathrm{ml} \times 10$.)

The clinical course was marked by soft-tissue and urinary-tract bleeding. After an infectious cause of the fever was ruled out, prednisone $60 \mathrm{mg}$ /day orally was initiated. This was subsequently increased to $100 \mathrm{mg}$ daily in divided doses. The patient required multiple blood and platelet transfusions over the next 4 weeks while still on $100 \mathrm{mg}$ prednisone daily. Because of no apparent response to prednisone, $1 \mathrm{~g}$ of intravenous methylprednisolone was given every morning on 3 successive days. The blood picture stabilised, and subsequently the patient required no further blood product transfusions. Improvements in haemoglobin, the platelet count, and fibrin split products were seen in the next 5-14 days. Repeat FANA was 1:1280. The CH50 returned to normal at $37 \%$, and the sedimentation rate decreased to $70 \mathrm{~mm} / \mathrm{h}$ (Westergren). The patient was continued on prednisone $50 \mathrm{mg}$ twice daily orally and was successfully tapered to $20 \mathrm{mg}$ of prednisone daily as an outpatient without relapse of her haematological conditions.

\section{Discussion}

Our first patient had multiple features of lupus erythematosus, ${ }^{7}$ including fevers, leucopenia, alopecia, proteinuria, arthralgias, and myalgias. In addition serum FANAs were positive and serum complement levels low. While her renal involvement as shown by proteinuria and proved by renal biopsy preceded onset of central nervous system manifestations of SLE, this was not of an immediate, lifethreatening nature. Initially she had shown improvement of her creatinine clearance, decrease in proteinuria, and reduction in fever and skin rash on oral prednisone. After the onset of grand mal seizures and high fever accompanied by mental obtundation, she rapidly deteriorated despite large increases in the dosage of prednisone and anticonvulsants. Her response to intravenous pulses of methylprednisolone was dramatic, with resolution of fever, cessations of seizures, and a return to normal mentation. Return to normal of serum complement components, decrease in erythrocyte sedimention rate, and a fall in serum IgG levels confirmed her response to therapy (Table 1).

Our second patient had arthralgias, alopecia, fever, and high titre FANA, but her major manifestations of SLE were haematological. These included haemolytic anaemia. thrombocytopenia, and disseminated intravascular coagluopathy. These features continued despite therapy with $100 \mathrm{mg}$ of oral prednisone daily for several weeks and required multiple transfusions of blood and platelets. After pulse therapy with methylprednisolone she required no more transfusion and had a reversal of the clinical parameters of coagulopathy (Table 2). Serum complement levels and erythrocyte sedimentation rate improved promptly.

The use of methylprednisolone pulses for lupus nephritis has been reported to be of value. ${ }^{4-6}$ The regimens described consist of 3-5 days of daily intravenous methylprednisolone and are essentially the same as described in the present patients. Use of this therapy has not been previously reported in patients with nonrenal complications of SLE.

Corticosteroid effects on both the inflammatory and immune responses have been demonstrated in both normal volunteers and ill patients. ${ }^{8}$ Specific anti-inflammatory effects that have been demonstrated include decreased availability of inflammatory cells, ${ }^{9}$ interference in inflammatory cell function. ${ }^{10}$ and suppression of noncellular, inflammatory reactions. ${ }^{11}$

Table 1 Laboratory and clinical parameters of patient 1 before and after pulse therapy with intravenous methylprednisolone

\begin{tabular}{lllll}
\hline & Seizures & Fever & Serum C4 & $\begin{array}{l}\text { Westergren } \\
\text { sed.rate }\end{array}$ \\
\hline Before pulse & $\begin{array}{l}\text { Many with } \\
\text { coma }\end{array}$ & $-38.5^{\circ} \mathrm{C}$ & $\begin{array}{l}9 \mathrm{mg} / 100 \mathrm{ml} 88 \mathrm{~mm} / \mathrm{hour} \\
(90 \mathrm{mg} / \mathrm{l})\end{array}$ \\
After pulse & None & $<37.5^{\circ} \mathrm{C}$ & $\begin{array}{l}32.8 \mathrm{mg} / 10018 \mathrm{~mm} / \mathrm{hour} \\
\mathrm{ml}(328 \mathrm{mg} / \mathrm{l})\end{array}$ \\
\hline
\end{tabular}

Table 2 Laboratory parameters of patient 2 before and after pulse therapy with intravenous methylpredinsolone

\begin{tabular}{|c|c|c|c|c|}
\hline & Haemoglobin & $\begin{array}{l}\text { Platelet } \\
\text { count }\end{array}$ & $\mathrm{CH} 5 \mathrm{O}$ & $\begin{array}{l}\text { Fibrin split } \\
\text { products }\end{array}$ \\
\hline Before pulse & $7.0 \mathrm{~g} / \mathrm{dl}$ & $\begin{array}{l}13000 / \mathrm{mm}^{3} \\
\left(13 \times 10^{9} / \mathrm{l}\right)\end{array}$ & $17 \%$ & $>40 \mu \mathrm{g} / \mathrm{ml}$ \\
\hline After pulse & $13 \mathrm{~g} / \mathrm{dl}$ & $\begin{array}{l}150000 / \mathrm{mm}^{3} \\
\left(150 \times 10^{9} / \mathrm{l}\right)\end{array}$ & $37 \%$ & $<20 \mu \mathrm{g} / \mathrm{ml}$ \\
\hline
\end{tabular}


Many immunological functions also are altered by steroid administration. ${ }^{8}$ Serum IgG levels may be reduced by high doses of intravenous methylprednisolone owing to both increased catabolism and decreased production of IgG. ${ }^{12}$ The ratio of $\mathrm{IgG}$ to antigen may be altered, and changes in the size of immune complexes may occur. This latter finding may lead to complexes with varying propensity to cause immune deposition in kidneys ${ }^{13}$ and possibly other systems. Medium-sized complexes are most often implicated in renal disease and are reduced in number by intravenous methylprednisone but possibly not by oral prednisone, though this is not clear. ${ }^{13} 14$

Absolute numbers of circulating $\mathrm{T}$ and $\mathrm{B}$ cells are dramatically reduced by intravenous methylprednisolone. ${ }^{15}$ While adult human lymphocytes are relatively insensitive to lysis by corticosteroids, ${ }^{16}$ these high doses routinely decrease circulating lymphocyte numbers within 6 hours of administration. Such alterations in lymphocyte populations, with elimination of lymphokine-producing cells, might alter favourably the clinical picture in patients with SLE. ${ }^{4} 15$

Recent evaluation by Fan et al..$^{14}$ of pulse therapy in rheumatoid arthritis casts some doubt on the relative role of the immune mechanism versus anti-inflammatory effects of methylprednisolone. However, overall benefit in clinical parameters was observed acutely, suggesting anti-inflammatory effect was more important in these patients. The prompt clinical response of the 2 patients reported here, as well as an improvement in serum complement levels and other serological tests, suggests that high-dose intravenous methylprednisolone may also lead to favourable immunological changes. Although the possibility of maintaining such a response on smaller, oral doses of corticosteroids is not clear, the course in these 2 patients suggests this may be feasible. The rapid improvement of these patients with intravenous pulse therapy suggests that this therapy may be of use in life-threatening, nonrenal lupus erythematosus. Unlike renal SLE, these nonrenal manifestations are occasionally acute and self-limiting. Such a pulse may therefore be of a long-range benefit by hastening recovery from haematological or central nervous system complications of SLE.

Supported by grants from the Veterans Administration Medical Center (MRIS 583-0888), United States Public
Health Service, National Cancer Institute (1 RO1 CA22141 and 1 RO1 CA23886), National Institute of Arthritis, $\overline{\bar{\omega}}$ Metabolism and Digestive Diseases (AM 20582), from the Arthritis Foundation, and the Grace M. Showalter Foundation.

\section{References}

1 Bell P R F, Briggs J D, Calman K C, et al. Reversal of $\vec{\circ}$ acute clinical and experimental organ rejection using large doses of intravenous prednisolone. Lancet 1971; 1: 876-880.

2 Feduska N J, Turcott J G, Gikas P W, Bacon G E, ભે Penner J A. Reversal of renal allograft rejection with intravenous methylprednisolone 'pulse' therapy. Surg Res ç 1972; 12: 208-215.

3 Cole B R, Brocklebank J T, Kienstra R A, Kissane J M. 'Pulse' methylprednisolone therapy in the treatment of severe glomerulo-nephritis. Pediatr 1976; 88: 307-314.

4 Cathcart E S, Idelson B A, Scheinberg M A, Couser W G. 옥 Beneficial effects of methylprednisolone 'pulse' therapy in diffuse proliferative lupus nephritis. Lancet 1976; 1: D 163-166.

5 Nebout T, Sobel A, Lagrue, G Intravenous methylprednisolone pulses in diffuse proliferative lupus nephritis. Lancet 1977; 1: 909

${ }^{6}$ Ponticelli C, Tarantino A, Piotelli P, Invernizzi F. High dose methylprednisolone pulses in active lupus nephritis. Lancet 1977; 1 : 1063.

7 Cohen A S, Reynolds W E, Franklin E C, et al. Preliminary criteria for the classification of systemic lupus erythematosus. Bull Rheum Dis 1971; 21:643-548.

8 Fauci A S, Dale D C, Balow J E. Glucosteroid therapy: mechanisms of action and clinical considerations. Ann Intern Med 1976; 84: 304-315.

9 Boggs D R, Athens J W, Cartwright G E, Wintrobe M M. The effect of adrenal glucocorticosteroids upon the cellular composition of inflammatory exudates. Am J Pathol 1964; 44: 763-773.

10 Weisman G, Thomas L. Studies on liposomes, I. The effects of endoxin, endotoxin tolerance and cortisone on the release of acid hydrolases from a granular fraction of rabbit liver. J Exp Med 1962; 116: 433-450.

11 David D S, Grieco M H, Cushman P Jr. Adrenal glucocorticoids after twenty years. A review of their clinically relevant consequences. J Chron Dis 1970; 22: 637-711.

12 Butler W T, Rossen R D. Effects of cortiocosteriods on immunity in man. J Clin Invest 1973; 52: 2629-2640.

13 Levinsky R J, Cameron J S. Scotthill J F, Serum immune complexes and disease activity in lupus nephritis. Lancet 1977; 1 : 564-567.

14 Fan P T, Yu D T Y, Clements P J, Fowlsoton S, Eisman J, Bluestone $R$. Effect of corticosteroids on the human immune response: comparison of one and three daily 1 gram intravenous pulses of methylprednisolone. $J \mathbf{L a b}$ Clin Med 1978; 91 : 625-634.

15 Yu D T Y, Clements P J, Paulus H E, Peters J B, Levy J, Barnett E V, Human lymphocyte subpopulations. $J$ Clin Invest 1974; 53: 565-571.

16 Claman $\mathrm{H}$ N. Corticosteroids and lymphoid cells. N Engl J Med 1972; 287: 388-397. 